\title{
Somos Dign@s and Trayecto Dignidad: a National Campaign for Advocating Human Rights in Puerto Rico
}

\author{
Marinilda Rivera-Díaz ${ }^{1}$ - Juan Correa-Luna ${ }^{2}$. Natalie M. Álamo-Rodríguez ${ }^{3} \cdot$ Esterla Barreto-Cortés $^{4}$. \\ Valerie Paz-Zayas ${ }^{3} \cdot$ María de Lourdes Martínez- Avilés ${ }^{4} \cdot$ Nylca Muñoz-Sosa $^{5} \cdot$ Mabel T. López-Ortiz $^{6}$. \\ Yamil Ortiz-Ortiz ${ }^{1} \cdot$ Doris Pizarro-Claudio $^{4} \cdot$ Yanira Reyes-Gil $^{2} \cdot$ Randy Tejada-Duarte $^{4}$
}

Accepted: 12 April 2021 / Published online: 16 June 2021

(C) The Author(s), under exclusive licence to Springer Nature Switzerland AG 2021

\begin{abstract}
SomosDign@s, a collective, composed by students, professors, and human rights activists, concerned about the crisis of human rights and civil liberties in Puerto Rico designed a successful national campaign for human rights known as: "Trayecto Dignidad" or "The Journey toward Dignity." This educational campaign emulated the Freedom Riders initiative of the 1960s. Throughout this article, we discuss the participatory action research (PAR) methodology designed by Somos Dign@s which frames the work of our Trayecto Dignidad campaign. Our methodology is based on the theoretical approaches of De SousaSantos (2002) and his conceptualization of human rights as having to rise through a process of "Globalization from below"; that is, a process of globalization that allows oppressed classes to advocate for their human rights. Five campaigns have been implemented since 2011. Some results have shown the need: (1) to continue educating about human and civil rights; (2) to educate and reinforce public policies to address discrimination based on race, social class, and gender particularly in the work setting; (3) to universalize health services; (4) to conduct a debt audit and advocate for the right of people of Puerto Rico to self-determination (UN Resolution $1514 \mathrm{XV}$ ); and (5) to integrate a public policy education based on gender perspective on schools and declare the State of Emergency for the femicides.
\end{abstract}

Keywords Human rights $\cdot$ Puerto Rico $\cdot$ Social work $\cdot$ Participatory Action Research (PAR) $\cdot$ Trayecto Dignidad $\cdot$ Somos Dign@s

Marinilda Rivera-Díaz

marinilda.riveradiaz@upr.edu

1 Doctoral Program of Social Determinants of Health, Graduate School of Public Health, Medical Sciences Campus, University of Puerto Rico, San Juan, Puerto Rico

2 College of Law, Interamerican University, San Juan, Puerto Rico

3 Department of Psychology, University of Puerto Rico, Rio Piedras Campus, San Juan, Puerto Rico

4 Graduate School of Social Work, University of Puerto Rico, Rio Piedras Campus, San Juan, Puerto Rico

5 Graduate School of Public Health, University of Puerto Rico, Medical Sciences Campus, San Juan, Puerto Rico

6 Department of Social Work, University of Puerto Rico, Rio Piedras Campus, San Juan, Puerto Rico

\section{Introduction}

1"For most of our life as a nation, the history of civil and human rights in Puerto Rico is more the story of their absence and mockery than the story of their empire and development" (Monge, 1987, p. 145). Puerto Rico's colonial status has adversely impacted the social, economic, and cultural aspects of life on the island, including the fundamental human rights of our people. Since the beginning of the 20th century, a series of US Supreme Court cases (known as the Insular Cases) stated that Puerto Rico is a non-incorporated territory. According to the Insular Cases, Puerto Rico is an appurtenant territory, belonging to the USA, but not a part of the USA (Gelpí, 2017). As noted by Philip Alston, the United Nations Special Rapporteur on Extreme Poverty,

\footnotetext{
${ }^{1}$ A Spanish language short version of this article was submitted and approved for publication to UNESCO (United Nations Educational, Scientific and Cultural Organization).
} 
political rights and poverty are inextricably linked in Puerto Rico: "If it were a state, it would be the poorest in the Union. But it is not a state, it is a mere 'territory'. Puerto Ricans who live on the island have no representative with full voting rights in Congress and cannot vote in presidential elections, although they can vote in Presidential primaries. In a country that likes to see itself as the oldest democracy in the world and a staunch defender of political rights on the international stage, more than 3 million people who live on the island have no real power in their own capital." (Alston, 2018, p.8).

According to Muñoz Sosa et al. (2018): “In 2010, a group of students, professors, labor unionists, human rights activists and the public in general, protested in front of the main legislative building of 'El Capitolio' in the city of San Juan, Puerto Rico, against legislation to carry out budget cuts that affected public education, healthcare, and other public services in the island" (p. 131). Dozens of students, professors, and citizens in solidarity were beaten by security guards and the Puerto Rican police during the protest. This event fostered the development of a group of citizens named Somos Dign@s or "We Are Worthy".Somos Dign@s, as a collective, identified the need to (a) collaborate and join with other groups of human rights and community organizations to lobby for legislation regarding human rights; (b) support and accompany communities through social actions, and share documentation related to human rights; (c) investigate and document the knowledge, perceptions, and attitudes that people have about their constitutional, civil and human rights; (d) expose and document peoples' stories of struggle, frustration, contempt and anger; and (e) identify concrete actions that citizens can take to condemn and expose the government's human rights violations (Muñoz Sosa et al., 2018, p.132). The principles that have governed the work of the Somos Dign@s are (a)demand for social justice and equity in Puerto Rico, (b) promotion of respect for the Puerto Rican person, and (c) proclamation that we are all dignified people, who deserve to be valued by our government.

SomosDign@s is concerned about the crisis of human rights and civil liberties that Puerto Rico as a territory has always faced. We designed a successful national campaign for human rights known as "Trayecto Dignidad" or "The Journey toward Dignity." This educational campaign emulated the Freedom Riders initiative of the 1960s, which denounced human rights violations against African American citizens (SomosDign@s, 2011). Throughout this article, we discuss the participatory action-research methodology (PAR) designed by Somos Dign@s which frames the work of our Trayecto Dignidad campaign. Our methodology is based on the theoretical approaches of De Sousa-Santos (2002) and his conceptualization of human rights as having to rise through a process of "globalization from below"; that is, a process of globalization that allows oppressed classes to advocate for their human rights. This experience will be reviewed as a promising methodology that can be used to teach human rights, moving from a learning-only culture into a culture that is ready to take social action and to advance a human rights agenda through social work and the work of other professionals who are committed to advocate for social justice and human rights in Puerto Rico.

\section{Human Rights and Globalization from Below}

Navarro (2007) uses the term "globalization" to generally signify the application of neoliberal politics, reduction in the participation of the state in all dimensions of the economic and social life of people, deregulation in international trade, increase in capital and labor mobility, and elimination of social deals in the international economic order. In contrast, De Sousa-Santos (2002), when referring to globalization processes, distinguishes between "globalization from above" and "globalization from below" to highlight social relationships and processes in the globalization. "Globalization from above" comprises two types of relationships: globalized localism, and localized globalism. The first is a process in which a local phenomenon transcends geographic borders and establishes itself elsewhere. The second is defined as the specific impact of transnational practices and imperatives on local conditions that are thereby restructured to respond to transnational imperatives (De Sousa-Santos, 2002). An example of localized globalism, in Puerto Rico as a colony of the United States, could be the imposition of neoliberal and colonial policies that affect the guarantee of the social rights of people. Examples include closure of hundreds of public schools (denying our children's right to education), privatization of health services (our people's right to health), expropriation of land and movement of communities (our people's right to housing), reduction of pensions (our people's right to social security), and being forced to pay an external debt.

Regarding globalization from below, De Sousa-Santos (2002) identifies two types of relationships: cosmopolitanism and issues that affect the heritage or the common legacy of humanity. Cosmopolitanism is the process of "the crossborder solidarity among groups that are exploited, oppressed or excluded by hegemonic globalization" (De Sousa-Santos, 2002, p.43). Likewise, De Sousa-Santos (2002) indicates that the predominant forms of domination do not exclude the opportunity for nation-states, regions, classes or social groups and their allies to organize transnationally in defense of perceived common interests, and to use to their benefit and the capabilities for transnational interaction created by the world system. It is here that this neoliberal and destructive process for humanity could be reversed if it is presented from the bottom up, as a counter-hegemonic process (Rivera Díaz, 2018). 
In this sense, the use of a critical human rights framework could be useful to accompany the diverse groups that advocate for justice and social change. Somos Dign@s, supported by the conceptualization of globalization from below and recognizing the importance of social movements in the defense and expansion of human rights, launched the campaign Trayecto Dignidad (Muñoz Sosa et al., 2018).

\section{Trayecto Dignidad and the Campaign for Human Rights}

\section{PAR Methodological Approach}

The campaign of Trayecto Dignidad is designed within the methodology of the participatory action research (PAR). PAR is considered a subset of action research, which is the systematic collection and analysis of data with the purpose of acting and generating changes through the generation of practical knowledge, particularly in a short period (within one to three years, or less) (MacDonald, 2012). One of the main objectives of PAR is to establish the links and relationships between individual, collective, functional, and structural problems, as part of the search for collective solutions to those problems (Contreras, 2002). PAR develops constructive exchanges between researchers and communities in which all stages of the research and social intervention processes are done together (Selener, 1997). The central elements of PAR are the following: (a) it is considered a methodology for transformation or change, (b) it promotes participation and self-determination in the people who use it, and (c) it produces a dialectical relationship between knowledge and action. Together, these three elements make PAR an effective tool to give people access to knowledge about their sociopolitical situation. Furthermore, the process encourages people to appropriate the knowledge we have and to use it to guide their social action.

\section{Campaign Dimensions}

Trayecto Dignidad has integrated various dimensions of work throughout the campaign: (a) research dimension, $(b)$ artistic dimension, (c) educational dimension, and (d) sociopolitical action dimension. An instrument is developed to collect the knowledge and experiences of the population with links to the issue of human rights that was previously defined for the campaign (each campaign address different human rights issues) for the research dimension. Students from diverse disciplines learn on each campaign about PAR implementation methodology. Also, this experience exposes students to an academic and community experience of professional and personal growth through direct contact with citizens while collecting relevant quantitative and qualitative data on the experiences of the people of Puerto Rico with the issue of human rights under study. This information is used to create proposals that will guarantee of human rights. The research protocol is submitted to the Committee for the Protection of Human Subjects on Research to protect the rights and well-being of participants.

The artistic dimension exposes our message about human rights through the arts. The organization "Sembrando Conciencia" or "Sowing Awareness," made up of students who are artists at the School of Plastic Arts of San Juan who are musicians and artists, apply the theater-street technique to captivate citizens during the days of the campaign. Street-theater performances integrate techniques of the Theater of the Oppressed developed by Brazilian actor Augusto Boal and Pangiatis Assimakopoulos. For Boal, the popular theater is to be performed by the people and for the people and not by the bourgeoisie. The purpose of the Theater of the Oppressed is to expose systematic oppression and exploitation within common situations (Coudray, 2017).

As part of the educational dimension, 1500 educational archives were prepared and distributed at each stop made during the trip. Also, a sequence of training is carried out for all staff participating in the campaign. Public conversations are also held in public spaces, commercial malls, and universities during the 3-day tour. Regarding the dimension of socio-political action, Somos Dign@s, together with other organizations, participates in various political activities, reiterating their support for the defense of human rights through their participation in public hearings, demonstrations in the Legislative Assembly, and adoption or denunciation of legislative projects that could advance or impair the state of human rights in the nation.

\section{Implementation and Remembrance}

Every two years, the collective Somos Dign@s takes on the task of designing this national human rights research and education campaign according to a selected topic (see Table 1).

The campaign emulates the 1961 Freedom Riders initiative, which denounced human rights violations against African Americans (Smith, 2009) (see Fig. 1). The Freedom Riders faced racial discrimination regulations that some states still maintained against blacks and Latinos, who remained segregated even though the US Supreme Court had already decided that racial discrimination was illegal (United States Supreme Court, 1954). That is why a group of passengers decided to hop on interstate buses and travel into the southern USA to organize and create awareness about the injustice of racial discrimination (VOA, 2011). 
Table 1 Human rights theme selection overview of 2011-2019 campaigns

\begin{tabular}{|c|c|c|c|}
\hline Year & Campaign & Human rights theme & Theme selection rationale \\
\hline $\begin{array}{l}2011 \\
\text { March 26-28 }\end{array}$ & Trayecto Dignidad 1 & $\begin{array}{l}\text { Knowledge, perception \& importance of human } \\
\text { rights }\end{array}$ & $\begin{array}{l}\text { Government violations of civil liberties and human } \\
\text { rights in 2010, particularly during the strike of } \\
\text { the University of Puerto Rico }\end{array}$ \\
\hline $\begin{array}{l}2013 \\
\text { April 27-29 }\end{array}$ & Trayecto Dignidad 2 & Social and Racial discrimination & ACLU Report "Puerto Rico Island of Impunity" \\
\hline $\begin{array}{l}2015 \\
\text { March 21-23 }\end{array}$ & Trayecto Dignidad 3 & Right to health and health services & Deterioration of health services \\
\hline $\begin{array}{l}2017 \\
\text { March 25-27 }\end{array}$ & Trayecto Dignidad 4 & $\begin{array}{l}\text { Right of self-determination against US colonial- } \\
\text { ism }\end{array}$ & $\begin{array}{l}\text { PROMESA Law and imposition of FCB by U.S. } \\
\text { Congress }\end{array}$ \\
\hline $\begin{array}{l}2019 \\
\text { March 30-April } 1\end{array}$ & Trayecto Dignidad 5 & Gender-based violence & Increase in cases of femicides \\
\hline
\end{tabular}

Trayecto Dignidad, in remembrance of the Freedom Riders, has students, professors, and volunteers traveling around the island in three school buses, taking the following routes: Bus no. 1 travels along the northwest, southwest of the island; Bus no. 2 travels along the northeast and southeast of the island; Bus no. 3 travels through northwest, center, and southern part of the island (see Fig. 2). Bus stops are previously decided by Somos Dign@s route committee members in consensus with community-based groups throughout the island. Each bus makes strategically planned daily stops in public squares, commercials malls, beaches, and communities. Once buses stop at the agreed place, the artists perform their act. This promotes the agglomeration of people who observe the artistic presentation. Art allows for individuals to express their emotions and feelings; for advocates, it allows them to express what they want without the constraints of the colonial power. It is here that research assistants, comprising students and professors, approach

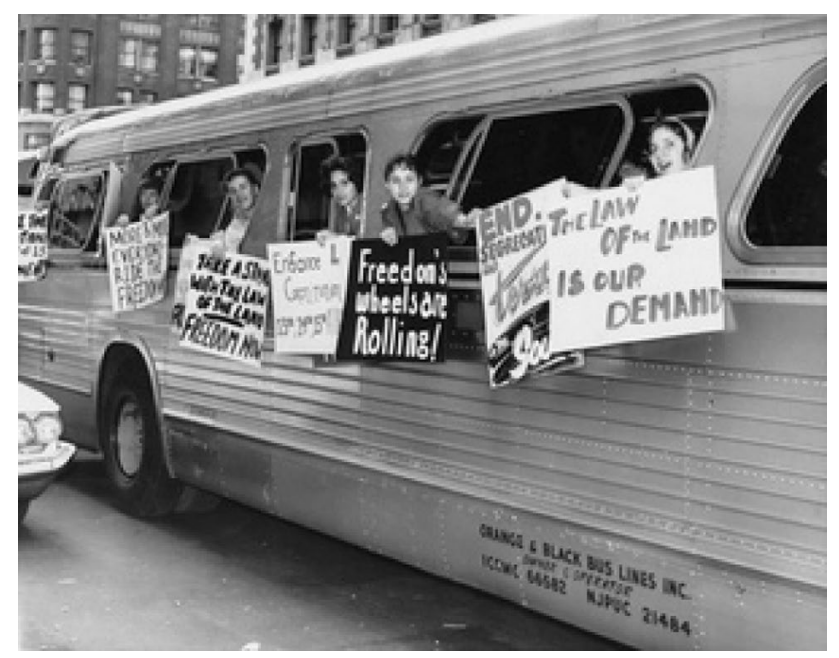

Fig. 1 Civil rights activists and students on interstate buses as part of the Freedom Riders demonstrations 1961. Image taken from: https:// www.flickr.com/photos/usembassythehague/8443765523 people to explain the campaign and ask for their voluntary participation in the investigation. All surveys are conducted anonymously.

To further the human rights agenda in Puerto Rico, Somos Dign@ $s$ found it necessary that the educational campaigns and all the results and data had to be widely known among the people and the policy decision-makers. Somos Dign@ created a media committee to arrange and schedule numerous radio and TV appearances with participant members and organizers of each "Trayecto" to talk about the event. After the conclusion of each Trayecto, a full disclosure of preliminary results and experiences was published in local and national newspapers on the island.Somos Dign@s also lobbied, along with other community-based groups and labor unions (A Su Salud PR, Alianza de Salud para el Pueblo, CABE, Asociación PKU, and SEIU) in favor of several important human rights legislation bills that later became law.

\section{Results}

Five educational campaigns or "Trayectos" have been developed since 2011. Each one addressed a specific human rights problem in Puerto Rico. A questionnaire was developed and prepared for each Trayecto by the Education and Research Committee of Somos Dign@s, composed of faculty members and students from Interamerican University and the University of Puerto Rico, human rights activists, and people from diverse interest groups. The following is a brief description of some relevant results of each Trayecto. A more detailed and complete description of results and data of all Trayectos are available at www.trayectodignidadpr.com.

In March of 2011, "Trayecto Dignidad 1" developed a questionnaire to measure the knowledge, perception, and importance of human rights on the island. Civil liberties and human rights violations by government officials and police officers during peaceful public protests in 


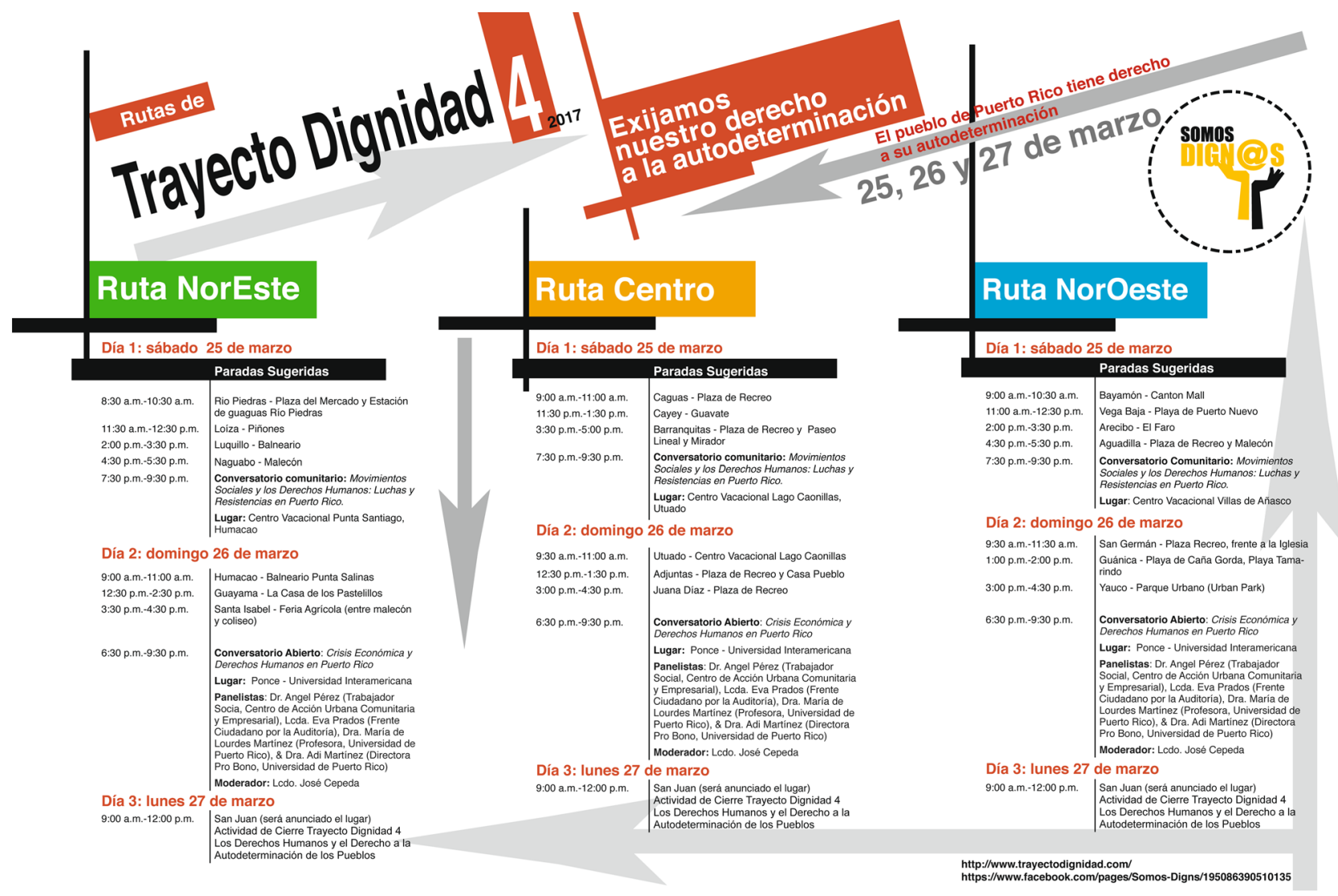

Fig. 2 Routes of stops made by Somos Dign@s in “Trayecto Dignidad 4" on March, 2017

San Juan, Puerto Rico, on June 30, 2010, was the main motivation of theme selection of Trayecto Dignidad 1. This first campaign revealed that $50.2 \%$ of Puerto Ricans could not mention a single civil right, and $58 \%$ could not mention a single human right $(N=900)$. These data reflects the lack of knowledge about civil rights in the population compared with a study conducted in 1959, where $47 \%$ of citizens could not mention a single civil right. Eighty percent $(80 \%)$ of the people interviewed considered that the government does not tell the truth to the people (Martínez, 2011). In summary, this Trayecto shows the need to continue using alternative methodologies to educate on civil and human rights in Puerto Rico.

“Trayecto Dignidad 2" was held in April of 2013; it compiled and analyzed experiences of discrimination in Puerto Rican society and the impact of racial prejudice on the island $(N=838)$. Theme selection for Trayecto 2 was based on Somos Dign@s concern of racial and social class discrimination in the island documented by several independent studies. One important report was made by the American Civil Liberties Union in June 2012. Chapter 4 of the report documents cases of excessive police force against low-income, Black, and Dominican communities (ACLU, 2012). Among the results,
$54 \%$ of participants indicated that they had been discriminated against between one or more times during their lives. Among the spaces where respondents reported having suffered the most discrimination were the workplace (57\%), in public places (38\%), school (35\%), government agencies (32\%), police (26\%), and shops or restaurants (25\%). The main reasons for discrimination were social class (42\%), nationality (35\%), and sex or sexual orientation (33\%). On the other hand, $48 \%$ indicated that they would do nothing if they were discriminated against or treated unfairly, while $44 \%$ indicated that they would always do something. This Trayecto shows the need to educate and reinforce public policies to address discrimination based on race, social class, and gender, particularly in the work setting.

“Trayecto Dignidad 3", carried out in March of 2015, investigated and studied peoples' experiences with health services and their knowledge regarding health rights and applicable legislation $(N=944)$ (Microjuris, 2015). The privatization of health services in the 1990s due to neoliberal measures taken by the government led to the accelerated deterioration of health services. This situation was denounced by various community-based groups such as the People's Health Alliance (Alianza de Salud para el Pueblo). Health, as the theme selection for "Trayecto 3," was based on such concerns. This campaign revealed, among other results, 
that $93 \%$ of the surveyed population considered health as a human right, $62 \%$ indicated that they would consider emigrating from Puerto Rico to obtain medical services, and $73 \%$ considered that there is discrimination for economic reasons in health services. While on the subject, $65 \%$ of the population was unaware of the services provided by the Office of the Patient Advocate. This Office was created in 2001, with the mission of enforcing the Bill of Rights of Patients under the Puerto Rico Health Reform. This Office is authorized to investigate complaints from citizens related to health. Among the recommendations made by the participants are cost reduction, a health system that covers everyone equally, depoliticization of the health system and greater citizen participation, quality of services, greater education, and support for health professionals, among others. The results of Trayecto 3 show the urgent need to universalize the health services in Puerto Rico.

In March 2017, “Trayecto Dignidad 4" addressed aspects related to the right to self-determination of people and US colonialism $(N=1135)$. This topic was chosen because of the approval of the PROMESA Law and the imposition of the Fiscal Control Board on Puerto Rico by the United States Congress. This campaign addressed the right to self-determination, the imposition of the Fiscal Control Board (FCB) by US Congress, and the public debt. Among the results, $86 \%$ of the participants agreed that the Puerto Rican debt should be audited, 69.8\% indicated that the FCB would increase unemployment, and $67.2 \%$ indicated that it would reduce basic social services. In addition, the survey revealed that $52.6 \%$ of the respondents understood that the FCB would violate people's human rights and would aggravate the economic crisis (50.4\%). The results show disagreement between the participants with the FCB and its implications over the population and the need to conduct a debt audit. Also, to advocate for the right of the people of Puerto Rico to self-determination (UN resolution $1514 \mathrm{XV}$ ).

Finally, "Trayecto Dignidad 5" is our most recent campaign. It was carried out in March 2019 under the theme "Violence, Genders and Human Rights" $(N=659)$. Various feminist organizations welcomed this campaign theme because they felt the femicides that occurred in 2018 warranted a declaration of the state of emergency and that structural violence had weakened the living conditions of the population, particularly those of women through school closures and the application of austerity policies. Trayecto Dignidad 5 administered a survey to 1033 people to explore knowledge about patriarchy and addressing the issue of gender violence from an intersectional perspective and the multiple manifestations of violence. However, only 652 answered the entire survey. The results revealed a positive relationship between age and internalized patriarchal discourse $(r=0.28, p<0.001)$ and religion frequency and internalized patriarchal discourse $(r=0.16, p<0.001)$, meaning that older age correlated with higher levels of internalized patriarchal discourse, and increased religion frequency correlated with higher levels of internalized patriarchal discourse. Also, a negative correlation was observed between internalized patriarchal discourse and education $(r=0.34, p<0.001)$, meaning that a higher level of internalized patriarchal discourse was observed in people who reported lower levels of education. The results of "Trayecto 5" shows the imperative need to integrate a public policy education based on gender perspective on schools and declare a State of Emergency as claimed by different feminist groups and diverse human rights activists in Puerto Rico.

\section{Discussion}

The media campaign and legislative lobbying played a major role in furthering the human rights work agenda established by Somos Dign@s with its five Trayectos. As a direct result of SomosDign@s's media campaign in numerous radio and TV talk shows and other professional academic and non-academic forums, on December 1, 2013, the most important and highest circulated newspaper on the island, El Nuevo Día, published in its front-page the major findings of the Trayecto 1 and Trayecto 2 campaigns. El Nuevo Día highlighted Trayecto 1 findings regarding low levels of civil and human rights knowledge and awareness among Puerto Ricans. They published the Trayecto Dignidad findings and dedicated a special edition on human rights issues during the whole month of December 2013. The thirty articles of the Declaration of Human Rights were analyzed by El Nuevo Día during the month of December 2013 (one article per day), and the articles were published along with in-depth analysis of data and graphics of the Trayectos 1 and 2. Members of SomosDign@s collaborated directly with the newspaper for these special-edition publications.

These publications got the attention of several members of the legislature. As a result, a legislative bill, Senate Bill 533, was presented to incorporate a human rights curriculum in the public educational system. The Bill directly references the Trayecto 1 findings on civil and human rights knowledge among the population. Although Senate Bill 533 did not become law, the need to incorporate a curriculum on human rights in the public school system requested by Somos Dign@s and other community-based organizations was finally heard in March 2018. That year, the Puerto Rican legislature approved an educational reform bill (Law number 85 of March 2018) that incorporated, among the duties of the Secretary of Education, the development of a Civil and Human Rights Program in the public educational system.

SomosDign@s presented data and research findings of Trayecto 2 (March 2013) related to discrimination issues to members of the Puerto Rican Legislature and lobbied with other community-based and labor union organizations, such as $C A B E$ and SEIU, in favor of a legislative bill (Senate 
Bill 238), which prohibited discrimination based on sexual orientation and gender identity in the workplace. The bill was finally approved that same year and became law (Law number 22, approved on May 29 of 2013).

Trayecto 3 data and findings of violations on health care rights and access to health care were presented to the Bar Association of Puerto Rico and its Constitutional and Human Rights Commission. The Constitutional and Human Rights Commission celebrated public hearings on health care issues and violations to health care rights on the island for 2 days (May 22 and 23 of 2013) as requested by Somos Dign@s and Trayecto 3 findings. Somos Dign@s made a formal presentation of data and result findings of Trayecto 3 during those public hearings along with dozens of other community-based organizations and citizens that participated.

Among the participants' organizations was the Association of PKU of Puerto Rico. The PKU Association represents patients suffering from a rare metabolic health disease known as phenylketonuria (also known as PKU). The PKU Association denounced, during the hearings, the Puerto Rico Department of Health for gross negligence by not providing the necessary medical treatment on the island to low-income children and adult patients suffering from phenylketonuria and other metabolic conditions. PKU, if not adequately treated, is a life-threatening condition. The PKU Association denounced how for more than ten years, they had tried to obtain help from the government without any success. The PKU Association was also denied legal representation to present their rightful claims in court by the legal aid programs on the island (Legal Services of Puerto Rico). After the hearings, Somos Dign@s lawyer members agreed to help the PKU Association of Puerto Rico, and in conjunction with the Legal Aid Clinic of the Interamerican University of Puerto Rico Law School, they presented a formal complaint in court against several private insurance companies, the Government of Puerto Rico, and its Department of Health. Shortly after, the case was settled in favor of the PKU Association. The judicial agreement included a formal acceptance on behalf of the Government of Puerto Rico, the Department of Health, and health insurance companies to provide, free of cost, the medical treatment and special amino acids formulas urgently needed by low-income, PKU and metabolic patients (Superior Court of Puerto Rico, Civil Case Num. SJ 2016CV0095).

Also,Somos Dign@s supported the PKU Association in its efforts to create a specialized clinic for PKU patients and patients with other metabolic diseases. Although the PKU Association had lobbied for more than ten years for the approval of a legislative bill for the creation of a specialized clinic for PKU patients, the bill was always rejected at the last moment. Members of Somos Dign@s lobbied along with the PKU Association and helped in scheduling important legislative and executive meetings in favor of House Bill 1099, which created a specialized clinic to provide all necessary special medical needs for patients with PKU disease and other metabolic conditions. The bill was finally approved that same year and is known as Law Number 139, approved on August 8, 2016.

Data and findings from "Trayecto Dignidad 1, 2 and 3" were also included as part of an extensive report prepared by more than 40 community-based organizations in Puerto Rico for the Inter-American Commission on Human Rights in Washington D.C. on April 4, 2016. The report was coordinated by the Human Rights Clinic of the Interamerican University of Puerto Rico Law School in San Juan. The report titled Public Debt, Fiscal Policy, and Poverty in Puerto Rico provided information to the Commission on fiscal policies adopted in Puerto Rico by the USA and the territorial government recommendations on how to face the economic crisis and how these measures had lessened the rights to education, housing, work, health, access to public information, and access to justice. This report was also referenced in another report presented before the same Inter-American Commission on Human Rights in December of 2017, after Hurricane Maria, titled Environmental Justice and Poverty in Puerto Rico (Justicia Ambiental y Pobreza en Puerto Rico, December 2017).

Findings of Trayecto 3 were also used to lobby in favor of House Bill 1185. This bill created, for the first time in the history of Puerto Rico, a multi-sector health council composed of professional care providers, health organizations, and nongovernmental community-based organizations with authority to study and recommend to the local government the adoption of a universal health care system under human rights parameters. The bill states clearly that the model to be recommended by the council must be based on the public policy recognition by the Commonwealth of Puerto Rico, that health care is a human right and a matter of ethical nature and social justice considerations, and as such shall always be above of all or any profit motive. The bill became law on December 22, 2016 (Law number 235, December 22 of 2015).

Research findings from Trayecto 4 (2017) and 5 (2019) were also widely published on the island throughout local and national media. Trayecto 4 revealed the high levels of dissatisfaction and rejection by the people, who were interviewed, against the measures imposed by the Fiscal Control Board established by the US Congress without the consent of the people of Puerto Rico. Trayecto 4 also revealed the levels of indignation against local corruption, colonialism, and the violation of self-determination rights. A highly respected community-based organization called Frente Ciudadano por la Auditoría de la Deuda (Citizens in favor of auditing the public debt) has requested from the local government the need for a civil audit of the public debt by an independent committee. The group used Trayecto 4 findings to reaffirm its request to audit the public debt and how the majority of the people of Puerto Rico are in favor of an audit. Although the FCB and the local government have rejected this idea, the request is still strong among a vast majority of the population. 
Femicides in Puerto Rico is an alarming problem. In 2018, 25 women were murdered. During the present year and as of December 2020, 49 women have been murdered. Somos Dign@s, as other community-based organizations and feminist organizations like Coordinadora Paz para la Mujer and Colectiva Feminista en Construcción denounced the government's inaction to declare the State of Emergency. Trayecto 5 designed the first questionnaire to measure levels of internalized patriarchy. The results revealed correlations between gender, age, education, and religious beliefs with high levels of internalized patriarchy. At the beginning of 2019, the governor of the island, his close inner circle of friends, and government officials, in a number of phone messages or chats that were made public, clearly revealed their culture of misogyny and patriarchal ideology. The nearly 900 pages from the messaging app Telegram was finally published by Puerto Rico's Center for Investigative Journalism. Governor Ricky Rosselló and 12 top aides and cabinet members exchanged profanity-laced, homophobic, and misogynist messages about fellow politicians, members of the media, celebrities, and others in a scandal that many referred to as "the Ricky Leaks." The messages were sent in December 2018 and January 2019. Governor Rosselló even referred to Melissa Mark-Viverito, the Puerto Rico-born former speaker of the New York City Council, as a "whore."

Feminist groups; community-based organizations; human rights organizations, including Somos Dign@s, labor unions; and human rights activists joined efforts to organize and mobilize more than a million people to the streets, requesting Governor Ricky Rosselló resign as governor of Puerto Rico, during the summer of 2019. The historic mobilization was the result of decades of indignation caused by the acts of corruption and disrespect to human rights by colonial governments. Governor Rosselló resigned on July 24, 2019.

SomosDign@s has recently launched a web page with data, research findings, and relevant documents of all its Trayectos. The web page also includes a photo gallery of each Trayecto and educational human rights articles. Due to present circumstances with the COVID-19 pandemic, the site will serve as an important tool in its commitment to serve the people of Puerto Rico and its struggle for political, social, and economic justice. The page can be accessed at www.trayectodignidadpr. com (Somos Dignos, 2020).

\section{Conclusion}

The "Trayecto Dignidad" national campaign and the Participatory Action Research methodology are promising practices that have multiple benefits for both students and the people of Puerto Rico. On the one hand, the students (a) have the opportunity to educate themselves on human rights from an interdisciplinary perspective; (b) participate in the data collection process allowing them to approach the social reality from the experiences of the surveyed citizens; (c) reflect on the state of the human rights situation based on the approach and narratives of citizens, developing a greater sensitivity to them; (d) value research studies as fundamental tools for transforming the structural conditions that promote the violation of human rights; and (e) recognize that our colonial condition and the economic system that governs it damages the dignity of every human being in Puerto Rico.

On the other hand, Trayecto Dignidad combines various educational modalities and strategies to raise awareness of human rights violations of the people in Puerto Rico and its colonial status. The investigations carried out with the previously described methodology have resulted in the approval of legislative projects, legal actions and accompaniment of vulnerable groups, press discussions on the status of human rights on the island, public hearings in the legislature, academy, the Bar Association of Puerto Rico, and presentations in forums, among others. In short, our campaign produces positive results for our people. Furthermore, it recognizes that any solution to the historical human rights crisis that the island faces must consider the current colonial condition of Puerto Rico. It is important to recognize that colonial and neoliberal ideology devalues human dignity. This ideology does not take seriously the importance of human rights in society. Recognizing human rights means putting people at the center of all political decisions and treating each person with the dignity and respect they deserve by placing the common good over the interests of (individual) property rights and the profit motive (Quigley, 2006). The ignorance about our human rights and civil liberties explored in our first campaign and the manifestations of discrimination and xenophobia, the violation of the right to health, self-determination, and genderbased violence (GBV) in Puerto Rico are the products of a patriarchal society based on a capitalist discourse of a power structure called colonialism, and of economic and social policies framed in these principles that undermine the dignity of our people.

Levels of government mistrust and discrimination identified in our research are similar to those experienced by Hispanics and Puerto Rican Communities in the USA (Rainie et al., 2019). But it is important to point out that the share of US Hispanics who live in poverty is $19 \%$ while $23 \%$ of Puerto Ricans live in poverty in the 50 states and Washington DC (Bustamante et al., 2017). In September of 2017, the New York Times reported that nearly half of American citizens do not know Puerto Ricans are fellow citizens (Dropp \& Brendan, 2017). In a country where its former president referred to Puerto Ricans as poor and dirty people, this should not surprise us. The president even suggested to his former administration official Miles Taylor whether it was possible to swap Puerto Rico for Greenland (Taylor, 2020). Article II section one of The Bill of Rights of the Constitution of the Commonwealth of 
Puerto Rico states: "The dignity of the human being is inviolable." The question is how much longer the government of the USA will postpone its obligation to recognize the full validity of this phrase for our nation.

Acknowledgements The co-authors want to thank all the collaborators of Trayecto Dignidad and Somos Dign@s. For the past 10 years, national Trayecto Dignidad campaigns have been possible thanks to the support of more than twenty organizations, including academic institutions, community organizations, professional organizations, foundations, and workers' unions that sponsor the activities from the Somos Dign@s. In addition, the commitment of hundreds of students from diverse disciplines, social and economic contexts, and professors who bring the classroom to every corner of Puerto Rico has made possible a real practice in social justice since 2011.

\section{References}

Alston, P. (2018). Report of the Special Rapporteur on extreme poverty and human rights on his mission to the United States of America. General Assembly, Human Rights Council. A/HRC/38/33/Add.1 June 18-July 6, 2018. https://digitallibrary.un.org/record/1629536

American Civil Liberties Union (ACLU). (2012). Island of Impunity: Puerto Rico's Outlaw Police Force. June 2012. https://www.aclu. org/files/assets/islandofimpunity_20120619.pdf

Bustamante, L. N., Flores, A. \& Sono, S. (2017). Facts on Hispanics of Puerto Rican origin in the United States. Pew Center Research Center. https://www.pewresearch.org/hispanic/fact-sheet/u-shispanics-facts-on-puertorican-origin-latinos/

Contreras, R. (2002). Participatory action research (IAP): reviewing its methodologies and potential. 9 Social Policy Series. CEPAL, United Nations.

Coudray, S. (2017). The theater of the oppressed. Culture Matters. https://www.culturematters.org.uk/index.php/arts/theatre/ item/2455-the-theatre-of-the-oppressed

De Sousa-Santos, B. (2002). Toward a multicultural conception of human rights. In Hernandez-Truyol, Berta. Moral imperialism: a critical anthology, p.39. New York: New York University Press. https://www.ces.uc.pt/bss/documentos/toward_multicultural_ conception_human_rights.pdf

Dropp, K., \& Brendan, N. (2017, September 26). Nearly half of Americans don't know Puerto Ricans are fellow citizens New York Times. https://www.nytimes.com/2017/09/26/upshot/nearlyhalf-of-americans-dont-know-people-in-puerto-ricoans-are-fellow-citizens.html

Gelpi, G. (2017). The constitutional evolution of Puerto Rico and other U.S. territories: (1898-Present). Inter-American University of Puerto Rico, Metropolitan Campus.

MacDonald, C. (2012). Understanding participatory action research: a qualitative research methodology option. Canadian Journal of Action Research, 13(2), 42-43.

Martínez Mercado, E. (2011). Puerto Ricans do not know their rights. Investigative Journalism Center. http://periodismoinvestigative. com/2011/12/los-puertorriquenos-no-conocen-sus-derechos/
Microjuris. (2015). Health as a fundamental human right begins "Trayecto Dignidad 3". https://aldia.microjuris.com/2015/03/18/la-salud-comoderecho-humano-fundamental-inicia-trayecto-dignidad-3/

Monge, J. T. (1987). Los derechos humanos: Doscientos años de experiencia constitucional en Estados Unidos y su influencia en América Latina. (Human rights: two hundred years of constitutional experience in the United States and its influence in Latin America) celebrated at the Bar Association of Puerto Rico during October 16 and 17 of 1987. Revista del Colegio de Abogados de Puerto Rico, Enero-Marzo 1988, 49(1), 145.

Muñoz Sosa, N., Rivera Díaz, M., \& Correa Luna, J. (2018). Right to health in the oldest colony of the world: An interdisciplinary participatory action research. Journal of Critical Law Studies, 14(1), 119-144.

Navarro, V. (Ed.). (2007). Neoliberalism, globalization and inequalities, consequences for health and quality of Life. Baywood Publishing Company.

Puerto Rico House Bill 1185. (2015). Law 235 December 222015 Ley Núm. 235 de 2015 -Ley para crear el Consejo Multisectorial del Sistema de Salud de Puerto Rico. (lexjuris.com) Puerto Rico Senate Bill 533 (2013). https://noticiasmicrojuris.files.wordpress.com/2014/02/ ps533.pdf

Quigley, W. (2006). 101 revolutionary lawyering: Addressing the root causes of poverty and wealth. Washington University Journal of Law \& Policy. 20, 101-168. https://openscholarship.wustl.edu/cgi/ viewcontent.cgi?referer $=\&$ httpsredir $=1 \&$ article $=1244 \&$ context $=$ law_journal_law_policy

Rainie, L., Keeter, S. \& Perrin, A. (2019). Trust and distrust in America. Pew Research Center. https://www.pewresearch.org/politics/ 2019/07/22/trust-and-distrust-in-america/

Rivera Díaz, M. (2018). Derechos humanos en salud y Trabajo Social en Puerto Rico: Un ensayo reflexivo para una propuesta de acción (Human rights in health and social work in Puerto Rico: reflective essay for a proposal for action). Publicaciones Puertorriqueñas.

Selener, D. (1997). Participatory Action Research and Social Change. 2nd ed. New York: Cornell University. ISBN 9978-95-130-X

Smith Holmes, M. (2009, February). The freedom riders, then and now. Smithsonian Magazine. https://www.smithsonianmag.com/history/ the-freedom-riders-then-and-now-45351758/

Somos Dign@s. (2011). ¿Quiénes somos? Trayecto Dignidad. http:// www.trayectodignidad.com

Somos Dign@s. (2020). Trayecto Dignidad. http://www. trayectodignidadpr.com/

Taylor, M. (2020). Former Trump official says Trump wanted to trade "dirty" and "poor" Puerto Rico for Greenland. https://www.youtube.com/ watch?v=UVj-GUYj2BU

United States Supreme Court. (1954). Brown vs. Board of Education, 347 U.S. 483.

VOA (2011, May 23). Anniversary of "Freedom Riders". https://www. voanoticias.com/a/aniversario-de-los-freedom-riders--122512269/ 99487.html

Publisher's Note Springer Nature remains neutral with regard to jurisdictional claims in published maps and institutional affiliations. 